\title{
"Więcej krawędzi. Mniej słów". Pamięć i trauma w poezji Wioletty Grzegorzewskiej
}

Borbála Faragó

TEIKSTY DRUGIE 2016, NR 3, S. 142-153

DOI: $10.18318 /$ td. 2016.3 .8

$\mathbf{S}$ vante Lindberg twierdzi, że literatura może odgrywać rolę pośrednika w komunikacji między krajem osiedlenia i miejscem pochodzenia ${ }^{1}$. To właśnie na pochodzeniu często koncentrują się studia migracyjne $i$ to ono jest analizowane i poddawane egzotyzacji. Rzadko zdarza się teź, by migracja była traktowana w kategoriach uhistorycznionego procesu - znacznie bardziej powszechna jest tendencja, by skupiać się na momencie opuszczenia kraju ojczystego lub przybycia do nowego. Szok, jaki towarzyszy wyjazdowi z domu, stanowi kluczowy aspekt narracji migracyjnej, zwłaszcza jeśli wiążą się z nim rozmaite perturbacje, jednakże kształtowanie migracyjnej lub ponadnarodowej tożsamości nie jest wynikiem pojedynczego wydarzenia, ale przebiega w sposób ciągły. Dlatego też traktowanie

1 S. Lindberg Simon Harel's "Les passages obliges l'écriture migrante" and the Question of Migrant Literature as Intercultural Mediator in Quebec, w: Transforming Otherness, ed. J. Finch, P. Nynäs, Transaction Publishers, New Brunswick-New lersey 2011, s. 62 .

\footnotetext{
Borbála Faragó - dr,

wykłada na Filologii Angielskiej w St Patrick's College w Dublinie. Interesuje się współczesną poezją irlandzką i migracyjną. Wspótredagowała Facing the Other: interdisciplinary Studies on Race, Gender and Social /ustice in Ireland (2008), Landing Flaces: Immigrant Poets in ireland (2010) i Animals in/rish Literature (2015). Opublikowała tez Medbh McGuckian (2014). Kontakt: borbala. farago@gmail.com
} 
migracji jako procesu osadzonego w historyczności i pamięci stanowi skuteczną strategię. Narracja migracyjna nie jest zawieszona w próżni: funkcjonuje w obrębie innych, podobnych narracji i tym samym jest historycznie osadzona w szerszej opowieści publicznej. Ta ciągłość jest często pomijana, szczególnie w przypadku podobnych narracji wspólnych dla różnych narodowości. Celem mojego tekstu jest analiza poetyckich przejawów pamięci, zwłaszcza pamięci traumy lub cierpienia, w wybranych utworach Wioletty Grzegorzewskiej.

Literatura stroni od prostych reprezentacji cierpienia i straty: doświadczenie dzieli od wyobrażenia droga okrężna i niebezpośrednia, co znajduje potwierdzenie także w procesie czytania. Nie jest łatwo wracać pamięcią do traumatycznych wydarzeń, nic więc dziwnego, że wielu autorom z trudem przychodzi wspominanie i relacjonowanie historii przemocy. Między traumatycznym przeżyciem i ekspresją językową zdaje się istnieć pęknięcie. Linearna struktura często zawodzi, a niewypowiedziana groza traumy niszczy spójność narracji. Słowa, metafory i symbole mogą u dotkniętego traumą pisarza wyzwolić wspomnienia. Jednakże zdaniem Kali Tal „czytelnik, który nigdy nie doświadczył traumy ma do dyspozycji tę samą kulturową «bibliotekę» symboli, mitów i metafor, co jej ofiara, jednak nie ma dostępu do znaczeń znaku, które przywołują traumatyczne wspomnienia"2. Dlatego właśnie w przypadku literatury traumy istotna staje się etyka czytania. Zapis traumatycznych doświad czeń i wspomnień może wywołać instynktowną reakcję u dotkniętego traumą czytelnika, czytelnik zaś, który nie ma podobnych doświadczeń, może poczuć się jak intruz w cudzej bardzo osobistej przestrzeni. Niezależnie jednak od sposobu lektury Kali Tal słusznie zauważa, że „sedno literatury traumy stanowi odtworzenie i przepracowanie traumatycznego doświadczenia"3, a to wymaga od odbiorcy czujności i empatii. Dlatego siła oddziaływania interpretacji zależy od wrażliwości: w przypadku transkulturowej melancholii, straty i traumy najlepiej sprawdza się nie spojrzenie badawcze, ale empatia.

Nie ma wielu prac naukowych, które porównywałyby literacki dorobek różnych narodowości na przestrzeni wieków, gdyż najczęściej zakłada się, że wątkami narracyjnymi rządzą pochodzenie i wspólne doświadczenia. Jest w tym oczywiście sporo prawdy, jeśli spojrzeć na kraje pochodzenia (możemy

2 K. Tal Worlds of Hurt: Reading the Literatures of Trauma, Cambridge University Press, Cambridge, MA 1996, s. 16.

3 Tamże, s. 17. 
założyć, że doświadczenia nigeryjskich migrantów w XXI wieku cechuje wiele podobieństw, choć nie bez znaczenia są tu także czynniki ekonomiczne), jednakże doświadczenia związane z migracją i kształtowaniem ponadnarodowej tożsamości u różnych narodowości i w różnych epokach mogą okazać się znacznie bardziej zbieżne, niż mogłoby się wydawać. Jednakże analogie te pojawiają się tylko na poziomie indywidualnym, a więc w skali mikro, nie w makronarracjach grup, które łączy przynaleźność etniczna lub kraj pochodzenia. Jest to szczególnie istotne w odniesieniu do traumy migracyjnej. Doświadczenia życiowe mogą być podobne, jednak znane są przykłady wysuwania roszczeń do narracji traumy opartych jedynie na przynależności do tej samej grupy etnicznej. Może to prowadzić do egzotyzacji i protekcjonalnego traktowania pewnych narodowości - okazywania współczucia całej zbiorowości zamiast empatii w stosunku do narracji indywidualnych. Dlatego, podobnie jak Lindberg, uważam, że aby naprawdę „zrozumieć traumatyczny wątek, trzeba zejść na poziom mikrorelacji międzyludzkich i wsłuchać się w opowieść jednostki”, gdyż właśnie tam „zachodzi prawdziwa transkulturowa polityka".

Należy jednak podkreślić, że migracji absolutnie nie powinno się utożsamiać z traumatycznym przeżyciem. W dzisiejszym świecie łatwo jest podróżować i dla wielu osób przeprowadzka za granicę jest doświadczeniem pozytywnym i budującym, szczególnie jeśli towarzyszą jej odpowiednie warunki finansowe i sprzyjająca sytuacja rodzinna. Niemniej błędem byłoby również lekceważyć współzależność migracji i traumy. Aby lepiej zrozumieć tę korelację, należałoby najpierw precyzyjnie zdefiniować oba pojęcia. Migracja jest tu rozumiana jako przemieszczanie się (dobrowolne lub niedobrowolne) między dwiema różnymi jurysdykcjami, przekraczanie międzynarodowych granic i przeprowadzka na dłuższy czas do obcego kraju. Tak szeroka definicja obejmuje uchodźców, osoby ubiegające się o azyl, imigrantów ekonomicznych i dobrowolnych imigrantów, którzy zdecydowali się zamieszkać gdzieś indziej. Nie ma zatem powodów, by zakładać, że samo doświadczenie migracji postrzegane jest jako traumatyczne. W niniejszym artykule trauma jest definiowana jako osobiste doświadczenie cierpienia, zdarzenie lub seria zdarzeń ponad siły jednostki, dla którego często trudno znaleźć adekwatną reprezentację językową. Definicja kładzie szczególny nacisk właśnie na jednostkę. Narracje traumy są zawsze narracjami pamięci, dlatego też rodzi się pytanie o to, dlaczego i jak zdarzenia są zapamiętywane, a nie

4 S. Lindberg Simon Harel's" "Les passages obliges lécriture migrante"..,, S. 72. 
czego dokładnie dotyczą wspomnienia. Można założyć, że narracje traumy należałoby badać z perspektywy doświadczenia i pamięci. To jednak rodzi kolejne pytania. W jaki sposób indywidualne lub zbiorowe doświadczenia są zapamiętywane i reprezentowane?

Wspomnienia stanowią fundament narracji doświadczenia. Jednakże akt pamiętania może zarówno zdestabilizować narrację, jak i ją uwierzytelnić. Oznacza to, że pamiętanie jest zawsze uzależnione od chwili obecnej. Reprezentacje wspomnień są siłą rzeczy interpretacjami zdarzeń przeszłych. Jest to szczególnie prawdziwe w przypadku konstruowania reprezentacji biografii, gdzie chwila obecna buduje spójną narrację ze skrawków pamięci. Na to, co pamiętamy, mają wpływ czynniki społeczne i psychologiczne - uczymy się, co należy zapamiętać, a czego nie, a także co możemy, a czego nie powinniśmy zapomnieć. Wspomnienia są też osadzone w kontekście kulturowym i politycznym i mają charakter intersubiektywny: dzielimy się wspomnieniami z innymi i za innych. Jednak w przypadku traumy proces reminiscencji ma nieco inny przebieg. Wracanie pamięcią do traumatycznych wydarzeń często nie jest łatwe, więc - jak twierdzi Julia Watson - pisarzom z trudem przychodzi wspominanie i opowiadanie o przemocy. Jak wyjaśnia badaczka, „w niektórych przypadkach problem przywołania i odtworzenia opowieści o poprzednim życiu wiąże się z koniecznością uporządkowania nieodpartej, choć często obezwładniającej siły pamięci i negocjowania jej fragmentarycznych ingerencji przy rosnącym (nawet jeśli niepełnym) zrozumieniu. Czasem język nie jest w stanie uchwycić, wyrazić ani przekazać dawnej grozy i konsekwencji jej przeżycia"5. Jak zatem przekonuje Watson, proces lektury ma dodatkową funkcję w przypadku literatury traumy. Jako czytelnicy mamy obowiązek uwzględnić rolę pamięci i zapominania w interpretacji przeszłości i teraźniejszości. Oznacza to, że czytanie wpływa na proces pamięci, a także na zapis aktów interpretacji, i że pozostaje wyczulone na osobiste, rodzinne i wspólnotowe aspekty zapominania i pamiętania 6 .

Reprezentacja osobistego traumatycznego przeżycia często stanowi o autentyczności dzieła literackiego, zwłaszcza jeśli autor deklaruje, że owo dzieło zawiera treści autobiograficzne. Zapisane doświadczenia wydają się jednak doraźne - Watson twierdzi, że są zawsze przekazywane za pośrednictwem

5 I. Watson, S. Smith Reading Autobiography:A Guide for Interpreting Life Narratives, University of Minnesota Press, Minneapolis-London 2010, s. 27-28.

6 Tamże, s. 30. 
pamięci i języka, a jako takie stają się „interpretacją przeszłości i naszego miejsca w konkretnej, określonej kulturowo i historycznie teraźniejszości"7. Ponadto należy założyć, że to właśnie doświadczenie jest czynnikiem konstytuującym podmiot mówiący. Podmiot autobiograficzny nie poprzedza doświadczenia. W naszym przykładzie tożsamościowa kategoria migranta powstaje w wyniku doświadczenia migracji, a zatem to podmiotowość kształtuje narrację tego doświadczenia. Jednakże, jeśli doświadczenie określa podmiotowość, można też założyć, że język tworzy wiedzę o doświadczeniu. Przykładowo dyskurs migracji staje się językiem, przez pryzmat którego podmiot migracyjny postrzega samego siebie (dlatego właśnie reprezentacje medialne mogą mieć potencjalnie szkodliwy wpływ, czego przykładem jest stosowanie przez irlandzkie media w stosunku do imigrantów terminu „nie-obywatel” [non-national], w oczywisty sposób nacechowanego pejoratywnie ${ }^{8}$ ). Doświadczenie istnieje również $w$ kontekście narracyjnym, co oznacza, że jest reprezentowane właśnie w opowieści. Jednak każda narracja podlega interpretacji, a narrator nie zawsze ją przedstawia. Proces czytania stanowi zatem także rodzaj uwierzytelnienia, który sprawia, że przedstawione doświadczenie zostaje zinterpretowane nieco inaczej albo wręcz od nowa. Autentyczność w kontekście traumy stanowi, rzecz jasna, kwestię ogromnej wagi. Narratorowi traumy zależy na tym, by jego opowieść była wiarygodna. Czytelnik jest zachęcany - pośrednio lub wprost - do tego, by przyjąć, że narrator stanowi „instancję o wyjątkowych kompetencjach", a tym samym, że należy uwierzyć w autentyczność jego doświadczenia. Łatwo to zauważyć, kiedy autor buduje swój autorytet, powołując się na tożsamość „uchodźcy”, ,azylanta” czy „wygnańca”. Jednak czytelnik może także sam dokonywać projekcji owych uwierzytelniających kategorii tożsamościowych, jakie wyłaniają się z biografii, co, rzecz jasna, podnosi szereg kwestii dotyczących metodologii i etyki czytania. Moim zdaniem dotyczy to szczególnie lektury poezji lub innych niefabularnych form literackich, gdzie rekonstrukcja doświadczenia ma jeszcze wyraźniej charakter wspólnego przedsięwzięcia czytelnika i autora. Jako czytelnicy musimy być świadomi własnych oczekiwań: czy chcemy, by emigracyjni twórcy uwierzytelniali

7 Tamże, s. 31.

8 Zob. G. Titley, No apologies for cross-posting: European trans-media space and the digital circuitries of racism, "Crossings: Journal Of Migration $\varepsilon$ Culture” 2014 no. 5 -

9 I. Watson, S. Smith, Reading Autobiography..., S. 33-34. 
swoją narrację w jakikolwiek sposób? A co jeszcze bardziej istotne, czy oczekujemy miarodajnych i wiarygodnych narracji emigracyjnych od autorów na emigracji?

Podsumowując, empatyczna lektura, o której piszę na wstępie, uwzględnia złożoność relacji między doświadczeniem i pamięcią, wpływ traumy na konstruowanie narracji i pozycjonalność czytelnika względem tekstu.

Wiersze Wioletty Grzegorzewskiej podejmują te kwestie zarówno na poziomie mikro, jak i makro. W tomiku Pamięć Smieny poetka koncentruje się na roli pamięci w procesie tworzenia tożsamości. Jednym ze sposobów, w jaki wspomnienie destabilizuje narrację, jest reprezentacja czasu. Wiersze Grzegorzewskiej stale dotykają pojęcia czasu. Niezależnie od tego, czy to przeszłość, teraźniejszość czy przyszłość, czas przedstawiany jest jako zjawisko zmienne, nieuchwytne i destabilizujące. Utwór Feerie to z pozoru nostalgiczne spojrzenie w przeszłość - zimowe wspomnienie z dzieciństwa, w którym podmiot liryczny zjeżdża z oblodzonego pagórka ,jak w transie”, z nadzieją, że „będzie tak całe ferie”. Jednak pragnienie, by uchwycić moment szczęścia pryska w ostatniej strofie, kiedy zachodzi słońce i

Mama woła: - Do domu! - więc wracam.

Oczka szklą się jak zamarzające planety.

"Oczka” - jeden z głównych organów percepcji, nieustannie się poruszają. Obserwacja nie może trwać w nieskończoność - prędzej czy później musimy mrugnąć lub odwrócić wzrok. Wspomnienia natomiast stwarzają iluzję trwałości: sięgamy po obrazy, jak po zamrożone okruchy czasu, wierząc, że została w nich uchwycona istota uczuć, jakie towarzyszyły doświadczeniu wizualnemu. Obraz „oczek jak zamarzające planety” symbolizuje niemoźność autentycznego wspomnienia: w akcie wspominania możemy przywołać pewne aspekty prawdziwego doświadczenia, które stało się naszym udziałem, jednak życie uszło z nich całkowicie. Metafora, wokół której skonstruowany jest przytoczony wiersz - „dom”, do którego wracają dzieci - znika w procesie wspominania niczym topniejący śnieg i kryjące się za horyzontem słońce.

Kwestię relacji między doświadczeniem i pamięcią porusza także wiersz Pamiéć Smieny. Jak wyjaśniono w Postowiu tomiku, tytuł odnosi się do „radzieckiego aparatu fotograficznego Smiena, [który] nie miał pamięci"10. Aparatem można zrobić zdjęcie, ale doświadczenia nie da się utrwalić na

10 K. Malszewski, Posłowie, w: Pamięć Smieny, s. 109. 
kliszy. Doświadczenie ma charakter ciągły i wielopłaszczyznowy: widzimy, słyszymy, czujemy - a także przetwarzamy, żeby móc później zrozumieć. Z tego powodu statyczny obraz stanowi fałszywe wspomnienie, ponieważ nie jest w stanie odtworzyć ciągłości doświadczenia. Tematem wiersza Grzegorzewskiej jest rozdźwięk między zamiarem utrwalenia doświadczenia na fotografii a niemoźnością jego zrealizowania. Juź pierwsza strofa, zaczynająca się od słów „Mam po niej”, sugeruje stratę. Pożegnalny dar bezimiennej kobiety to „dwa zdjęcia i przeczucie, / że coś nas łączy poza więzami krwi". Wiersz koncentruje się na relacji, której nie da się zamknąć w ramy obrazu. Centralnym motywem dwu kolejnych wersów jest zmienność:

Może podobna skłonność do wzruszeń,

Które utrwalała sowieckim aparatem.

Jednak tej „skłonności” nie sposób „uchwycić” w bezruchu, a jedynie w ruchu, paradoksie i ambiwalencji. Jednakże tam, gdzie zawodzi fotografia, w sukurs przychodzi język: słowa, takie jak „może” czy „skłonnośc”, wyrażają poczucie przemijalności, którym poetka próbuje nasycić swoją osobistą interpretację pamięci.

Druga strofa - stanowiąca w pewnym sensie centralną część wiersza ukazuje subiektywne rozumienie czasu w pamięci:

Po komunii ściemniały jej włosy.

Podarowany Poljot zatrzeszczał.

Sprężynka pękła. Przyspieszył czas

po pierwszej miesiączce. Obolałe

dzieciństwo nie zagoiło się do wesela.

„Ból” sugeruje zawieszenie liniowego czasu egzystencji, a w miejsce niezakłóconego biegu lat dzieciństwa pojawia się pęknięcie w postaci subiektywnego doświadczenia. W przytoczonych wersach pobrzmiewają złe przeczucia, a słowa takie jak „ściemniały”, „zatrzeszczal” czy „pękła” - a także aluzja do krwi miesiączkowej - sugerują traumę i stratę. Trauma, jak za Freudem wyjaśnia Cathy Caruth, to „rana umysłu”, która

inaczej niż rany fizyczne, nie jest prosta i uleczalna, ale stanowi raczej zdarzenie [...], którego doświadczamy zbyt wcześnie, zbyt nieoczekiwanie, 
aby móc je w pełni pojąć, a tym samym pozostaje niedostępna dla świadomości dopóki nie zaistnieje ponownie, po wielokroć, w koszmarach i powtarzających się działaniach tego, kto ową traumę przeżył."

Niezależnie od tego, czy wiersz traktuje o traumie, czy też o mniej dotkliwym bólu, powyższe wersy bardzo trafnie oddają poczucie zawieszonego czasu. Ostatnia strofa opisuje nudne, dorosłe życie kobiety, która "zaczęła się budzić" z monotonnej egzystencji, jaką wiodła „z przyzwyczajenia”. Niejasne jest jednak, czy to przebudzenie okazało się dość skuteczne, by stłumić ból dziecinstwa opisany w poprzedniej strofie. W ostatnim wersie utworu („Czy skończoność może się dłużyć?") pobrzmiewa zmęczenie, a także sugestia, że być może przebudzenie oznacza nie tyle nowy początek, ile nową świadomość, jak fatalne jest jej położenie. Doświadczenie emocji, które stary radziecki aparat próbuje bezskutecznie utrwalić, zostaje zatem zrekonstruowane jako strumień pamięci w dwuznacznych, potoczystych wersach.

Próba zrozumienia przeszłości stanowi temat wiersza Wszystko o moim ojcu, w którym podmiot liryczny nieśmiało próbuje skonstruować wspomnienie o swoim ojcu. Z tytułu wynika, że będzie to opis całościowy, że nic nie zostanie pominięte. Ojciec jest opisywany różnymi epitetami, począwszy od „wojownika”, ,kozetkowego onanizatora”, ,pszczelarza” czy „,króla hipochondryków". Wypowiadając się na przemian w drugiej i trzeciej osobie, podmiot liryczny próbuje sięgnąć do pamięci o ojcu z różnych perspektyw, a powtarzająca się killkakrotnie w utworze fraza „niech mnie pamięć myli” sugeruje, że wspomnienie może być nie do końca wiarygodne. Kruchość pamięci przenika cały utwór i stanowi dopełnienie słabości starzejącego się ciała ojca. Wiersz kończy opis monumentalnej postaci, „Don Juana wiejskiego”, ,króla hipochondryków", którego osobowość jest zbyt bogata, by zmieścić ją w ramach spójnego wspomnienia.W dwuwierszu zamykającym utwór („Niech będzie przeklęty ten sinawy zimorodek, / który wygrzebał gniazdo w twoim słabym sercu") zawarta jest nieco enigmatyczna metafora pamięci. Locus pamięci znajduje się właśnie w sercach bliskich, których pamiętamy - to, co wspominamy, to arbitralne, ulotne chwile porozumienia, znikające i pojawiające się tak szybko, niczym zimorodek podczas polowania. Wspomnienia bywają bolesne, a wracając pamięcią do życia bliskiej nam osoby, nieuchronnie myślimy

11 C. Caruth Unclaimed Experience: Trauma, Narrative, and History, John Hopkins University Press, Baltimore $1996,5.4$. 
także o jej śmierci. Wspomnienie, bez względu na to, jak piękne, podobnie jak ptak w przytoczonym wierszu, gnieździ się głęboko w bólu i traumie straty.

Czas jako centralna metafora pojawia się także w innym wierszu Grzegorzewskiej, w którym autorka porusza temat własnych doświadczeń na emigracji. Utwór Czas mew opisuje senną nadmorską miejscowość w Anglii, gdzie malownicze otoczenie zastyga w koszmarną rzeczywistość osoby „nie stąd”, outsidera. Podmiot liryczny „kręci się wolno”, „choruje na przewlekłe tygodnie", które nie przynoszą wytchnienia od nudy monotonnego otoczenia. W drugiej strofie pojawiają się wprawdzie odniesienia do ruchu („żaglówki kiwają się" „turyści [...] trwonią się" "poduszkowce uciekają"), niemniej wymowa opisywanej sceny pozostaje klaustrofobiczna i opresyjna. Podmiot - emigrantka tutaj nie pojawia się, a mimo to poczucie uwięzienia jest przytłaczające (wrażenie to potęguje się przez nawiązanie do zamknięcia - „zwijają pole golfowe" - w ostatnim wersie). Końcowy dwuwiersz to przejmujące wołanie o pomoc:

Zabierz mnie z tego raju, gdzie czuję się mdło

jak herbata z mlekiem. Zabierz, zanim wyparuję.

Swojskie, sielankowe otoczenie pozostaje poza zasięgiem emigrantki wypchniętej poza jego metaforyczne ściany. Czas tutaj to „czas mew”, a nie czas podmiotu lirycznego - kobiety, która w tym środowisku czuje się niewidzialna, „mdła” i niemal martwa. Jeśli przyjąć, że jest to migawka, zapisany w pamięci obraz określonej chwili, emigrantka jest tu nieobecna i nie zostanie zapamiętana jako integralny element naturalnego, rodzimego krajobrazu. Trauma w tym wierszu polega na niemoźności nawiązania istotnej interakcji między emigrantką-podmiotem lirycznym i obcym otoczeniem. Migawka bez pamięci, uchwycona za pomocą przestarzałego aparatu.

W Kołysance ${ }^{12}$ pojawia się kolejny motyw emigracyjny: oto robotnik, który pracuje w angielskim gospodarstwie w nadziei na lepsze życie. Wiersz obrazuje jego ciężki los także przez reprezentację czasu. Wers otwierający utwór („Śpij, jutro obejrzysz polską telewizję”) zachęca robotnika do tego, by zatrzymać czas i stworzyć alternatywny, utopijny świat marzeń, gdzie może on (zakładając, że bohaterem jest mężczyzna) „wrócić do kraju”, „rzucić plantację" i znaleźć „błogosławiony” moment wytchnienia. Ów alternatywny świat

12 W. Grzegorzewska Pamięć Smieny/Smena's Memory, przeł. M. Kazmierski, Off Press, London 2011, S. 59. 
jest zdecydowanym przeciwieństwem rzeczywistości, w której żyje robotnik, a polecenie „Śpij”, rozpoczynające każdą strofę, można interpretować jako agresywną (choć nieudaną) próbę wyrzucenia czasu poza jego zwyczajne tory. Kołysanka okazała się nieskuteczna, ponieważ „Noc na wyspie obiecanej jest krótsza" i brakuje miejsca na to, by tożsamość emigranta mogła się ukształtować. Grzegorzewska wielokrotnie nawiązuje do dysonansu czasowego, jakiego doświadczają emigranci podczas pobytu za granicą: niezależnie od tego, czy w nowym kraju czas staje w miejscu, czy też gwałtownie przyspiesza, podmiot-emigrant nie jest w stanie funkcjonować w tym samym rytmie, co potęguje w nim poczucie izolacji i samotności.

Próba znalezienia adekwatnych środków wyrazu dla opisanego powyżej dysonansu stanowi główny motyw jednego z najpiękniejszych wierszy w tym zbiorku, Bezsenność w Ryde. Wiersz rozpoczyna się cytatem z Kafki: „Od wszystkich rzeczy oddziela mnie próżnia / i nie pcham się nawet ku jej krawędzi", doskonale ilustrującym poczucie izolacji i strachu, które mogą towarzyszyć podmiotowi-emigrantowi w traumatycznym okresie przejściowym. Tytuł sugeruje, że nastąpiło wybicie ze zwykłego czasu: podmiot nie może zasnąć, a właściwie nie może zasnąć za granicą, w odróżnieniu od rodowitych mieszkańców kraju, którzy, jak można domniemywać, śpią zgodnie ze swoim czasem lokalnym. Pierwsza strofa opisuje siedzącego na framudze kota, który „wyłazi z siebie, aby dogonić dmuchawiec”. Ów ulotny cel („dmuchawiec”) można interpretować jako wymarzoną, nową tożsamość, utopijne poczucie przynależności, którego emigranci pragną tak bardzo, że „wychodzą z siebie”. Nawet jeśli takie odczytanie jest nieco naciągane, poczucie rozdwojenia tożsamości z pewnością charakteryzuje doświadczenie większości emigrantów, którzy, rozdarci między pragnieniem integracji a nostalgią, często odczuwają z tego powodu wewnętrzny dysonans. Druga strofa opisuje "Angielkę" (anachroniczne określenie), która "wypływa z wiktoriańskiej kamienicy". Uchwycona tutaj scena ma charakter ambiwalentny historycznie, ale jest dość precyzyjna pod względem geografii. Słyszymy jej „codzienne przekleństwa”, a kolejne dwa wersy ilustrują znacznie bardziej zinternalizowany pejzaż:

W nocy otwiera się próżnia, pęka w skroniach, nabita płaczem dziecka i gwizdem promów.

Kafkowska „próżnia”, oddzielająca podmiot od spójnej egzystencji - od „wszystkich rzeczy" - grozi pogrążonemu w bezsenności podmiotowi lirycznemu traumą pamiętania („płacz dziecka”) i obrazem wyjazdu ("gwizd 
promów"). Wydaje się zatem, że w niektórych przypadkach emigracja, zamiast zapewnić podmiotowi bezpieczną nową tożsamość, skutkuje raczej poczuciem utraty własnego „ja”., - Więcej krawędzi. Mniej słów” - ten przejmujący wers zamyka wiersz, sygnalizując niemożność wyrażenia słowami traumatycznego doświadczenia, które zyskuje jednak wyraz w kunsztownej frazie poezji Grzegorzewskiej.

W swojej poezji Wioletta Grzegorzewska bada rolę pamięci oraz kruchość naszego postrzegania czasu, próbując zgłębić sens znikającej przeszłości i niepewnej teraźniejszości. Jej bohaterzy-emigranci - zarówno ci istniejący w rzeczywistości, jak i wyimaginowani - borykają się z płynną toźsamością, w której zostają zakwestionowane uchodzące za utrwalone relacje między miejscem pochodzenia i celem podróży. Emigracja w wierszach Grzegorzewskiej to nie tyle wyjazd z domu i podróż do nowego kraju, ile raczej przemykanie chyłkiem przez złogi pamięci i percepcji, co podwaza zasadność przyklejania emigrantowi etykiety „innego”. Grzegorzewska dołącza tym samym do grona twórców emigracyjnych, którzy zacierają narzucone swoim podmiotom kategorie toźsamościowe ${ }^{13}$ : można raczej przyjąć, że doświadczenie emigracji zaowocowało u niej, podobnie jak u innych poetów-ekspatriantów, wykształceniem bardziej płynnego poczucia tożsamości, w którym doświadczenie to określa się jako proces konstruowania podmiotowości ${ }^{14}$. Istnieje zasadnicza różnica między definiowaniem migracji jako kategorii tożsamościowej a określaniem jej mianem konstytutywnego doświadczenia. Z punktu widzenia kraju docelowego traktowanie migracji w kategoriach tożsamości powoduje, że obraz imigrantów zostaje nie tylko uproszczony, ale potencjalnie także wypaczony. Jeśli przybyszów określa się mianem „innych" - „obcych", „nie-obywateli" - to gospodarze dyktują warunki relacji: "obcokrajowcy” i „obcy” muszą się dostosować do otoczenia, w którym zamieszkali. Jednak jeśli przyjmiemy, że migracja stanowi doświadczenie konstytutywne, interakcja zyskuje bardziej złożony i zrównoważony charakter, a to dlatego, że zrozumienie wymaga empatii. Lektura poezji dotykającej traumatycznych wspomnień otwiera przed czytelnikiem empatyczną interaktywną przestrzeń, w której kategorie tożsamościowe są gruntownie rewidowane. Czytając, bierzemy udział w opowieści o traumie i doświadczamy kruchości pamięci. Wiersze Wioletty Grzegorzewskiej umiejętnie prowadzą

13 Zob. B. Faragó Migrant Poet(h)ics, w: From Literature to Cultural Literacy, ed. N. Segal, D. Koleva, Palgrave MacMillan, Basingstoke 2014, s. 86-105.

14 J. Watson, S. Smith, Reading Autobiography..., s. 31. 
czytelników do empatycznego zrozumienia, co pozwala na bardzo osobistą, choć jednocześnie uniwersalną interpretację migracji jako doświadczenia konstytutywnego.

Przełożyła Katarzyna Gucio

\section{Abstract}

\section{Borbála Faragó}

STPATRICK'S COLLEGE, DRUMCONDRA

'More Edge. Less Words': Memory and Trauma in Wioletta Grzegorzewska's Poetry

Migrants' narratives do not exist in a vacuum: they have their places within similar narratives, historically embedded within a larger public story. This continuity is often overlooked, particularly when it comes to similar narratives shared by different ethnicities. The purpose of this paper is to investigate poetic manifestations of memory, especially trauma or pain memory, in a selection of texts written by Wioletta Grzegorzewska. Her poems consider the question of memory on both micro and macro levels. Her collection Smena's Memory, as this paper argues, investigates the role of memory in the process of identity creation.

\section{Keywords}

migration, memory, trauma, identity, transnationalism 